\title{
An Ethical Appraisal of Higher Education: Assessing Teacher-Student Friendship and Autonomy of Students in the Classroom
}

\author{
Kumar Neeraj Sachdev and Chetna Gupta
}

\begin{abstract}
We present in the paper an ethical appraisal of higher education focusing majorly on relevance and requirements of practicing democratic principles in higher education. We assess in this endeavor two ethical issues, namely teacher-student friendship, and autonomy of students in the classroom and argue for ethical infeasibility of teacher-student friendship and need for protection of autonomy of students. In connection with the latter, we argue for ethical restrictions on a teacher's advocacy of views because advocacy of views may unjustifiably lead to maintaining one's own position to elicit students' agreement in a topic of academic study in humanities and social sciences.
\end{abstract}

Index Terms - Autonomy of Students in the Classroom; Democratic Principles; Ethics in Higher Education; TeacherStudent Friendship.

\section{INTRODUCTION}

We begin with an ethical appraisal higher education and go on to elaborate relevance and requirements of democratic principles in higher education to justify various practices of higher education. And in continuation, to enhance our understanding of democratic principles and thereby of working teachers in higher education, we focus upon an assessment of two ethical issues, namely teacher-student friendship, and autonomy of students in the classroom.

\section{AN ETHICAL APPRAisAl OF HIGHER EDUCATION}

Ethics is a study of values to live a good human life and such a study of values usually takes place in the building of or extending the limits of an existing ethical framework. The ethical framework, for example, of virtues to live a good human life, or of fundamental moral principles of human conduct, happens to justify the presence and application of values in a human action, rule, or policy. It incorporates a moral outlook, which helps an individual human being to be able to take morally justifiable decisions in his or her life. "Ethics deals with values, with good and bad, with right and wrong" [8]. Thus, it helps to rationally justify the applications of various values in an individual's life such as integrity, discipline, honesty, truth, respect and so on to live a good human life.

Further, it may be argued that ethics influences behavior of individual human beings so that morally defensible choices may be made. Without ethical deliberations it is impossible for individual human beings to regulate their lives and act responsibly whether that is concerned with personal life or public life as there are many areas of public life for example, life of a citizen or life of a professional. In the field of education, which is a well-known example of a profession, it goes without saying that ethics plays an important role because a value-oriented approach is necessary to acquire information, skills, and knowledge.

It may be noted that education, in a great measure, forms the moral character of men [9]. Moral character is formed in an individual with a significant help from the pursuit of education if that is made available to him. Education provides better access to opportunities, resources, and power to an individual. However, there is an urgent need to move education from memorization of facts to creative thinking, from techniques of passive to active learning, from fragmented knowledge to contextual knowledge, from mechanistic to organic or ecological knowledge, from abstract to life-centric experiences, from discipline-specific to inter-disciplinary perspectives, from abstract principles to spiritual and ethical and lastly from subject to person and personality-centered education, if we want holistic benefits of education for all human beings.

The aim of education is to make an individual aware about everything such as man-made world and natural world and then the intricacies of relating values of human life in the two and in the relation among the two. To fulfil this aim, education is regarded as a process of developing individual's personality in physical, intellectual, spiritual, and social ways. It is also regarded as a way to facilitate learning, knowledge, skills, values, beliefs and habits of an individual. It is referred to as a comprehensive technique of overall development of an individual [4].

Ethics in education develops human sensibilities and an ability to make rationally correct judgements in one's life. It also develops the character of an individual and for this we need the working of democratic aspects in education in which free exchange of information and knowledge is required between a teacher and his students for the sake of holistic learning and growth of students. We need this to work at all levels of education especially at higher level of education because afterwards an individual human being comes directly in contact with the society and the world to live through his life [2].

Higher education is regarded as an important phase of training for an individual's identity formation in his life. It is

Chetna Gupta, BITS, Pilani, Rajasthan, India (e-mail: p20190504@ pilani.bits-pilani.ac.in) 
considered as a process of balancing global and contextual perspectives in building identities of individuals through teaching, research, and training. Higher education should also be taken as a process to strengthen democratic virtues, such as tolerance, truth, accountability etc. among the individuals as students by way of providing platforms to think and reflect upon issues in order to build a morally justifiable human identity [4].

\section{A REVIEW OF DEMOCRATIC PRINCIPLES IN HIGHER EDUCATION}

To establish democratic environment in education, teachers are required to uphold the principles of freedom of expression and equal access to students to freely express their opinions. The principle of freedom of expression creates conducive conditions under which teachers are able to cultivate and develop the capacity among students to analyse and critically reflect upon various democratic aspects of interacting people in the world.

We need to understand that academic freedom in this whole democratic process of academic environment is regarded as the holistic freedom of thought and speech to grow and help others to grow, which ought to be equally granted to both teachers and students. Through academic freedom both teachers and students tend to follow their own autonomous judgments in their pursuits to live good human lives. We may quote Gutmann in this regard, "To the extent that a participatory approach builds upon students' interests and elicits their commitment to learning, it may be considered more democratic than a disciplinary approach [5]."

The aim of higher education is to develop and protect individuality of students and teachers so that freedom of thinking and speech may prevail, and a better communication may build up between the teacher and the students. This leads to the flow and exchange of ideas without any fear. Ethics in Higher education becomes a vehicle to make people's thought and belief original and transparent. It may also be argued that a principle of non-discrimination, which treats everyone as equal and also provides respect to everyone, is to be followed in higher education. On the basis of caste, creed and color, no discrimination may take place in any institution or university admissions. So, it is required to maintain the democratic environment in education and to achieve this we need to infuse democratic freedom in education.

The democratic freedom in education is also required because students are expected to be critical thinkers. They need to reflect on certain issues particularly in humanities and social sciences. They observe, question, synthesize their learning and try to demonstrate their learning and understanding to others [5]. They give academic feedback to their teachers while critically examining their own behavior as both teacher and students are regarded as equal members of academic community. In such an academic environment, a question may arise: should they become friends?

\section{AN ASSESSMENT OF TEACHER-STUDENT FRIENDSHIP}

It is maintained that the teacher should not become friends with his students [7]. The reason being it is not possible for a teacher to become a friend of every student of his class. And if a teacher becomes friend with one or two students, then there is a possibility of partiality or favoritism. It can be claimed by a student that the teacher may give more marks or grades to his student-friend even though he may not deserve those marks [7], [3].

If a teacher is a friend of his student, then the problem of teaching impartially in the classroom may also arise. A teacher may not be able teach his student-friend in a manner that is fair to all students in the classroom because of the fact that the particular student is his friend. Markie maintains, "professors who become friends with their students, become friends with only some of them, and thus adopt a special attitude of concern for, and a special commitment to, the welfare of some of their students but not others. They are then likely to give those students who are their friends extra opportunities in instruction, advising and evaluation, even though being a friend is not a characteristic relevant to the distribution of these opportunities. They are likely to violate their moral obligation to give all students equal consideration [7]."

In continuation, we contend that there is a possibility that a teacher may provide more study material to his friend. As a teacher, it is his moral duty to teach each and every student of his class in the same manner. It is the duty of a teacher to maintain equal level of teaching and evaluation. If a teacher is providing extra help to only one student, then that is considered an act of partiality, which is apparently wrong.

If a teacher does not follow the principle of justice as proportional equality that like cases should be treated alike, and unlike cases should be treated differently in proportion to the relevant differences [1] then, he violates his moral duty of being a professional teacher. The argument continues that the teacher-student friendship limits a teacher's ability to be just to all students in the class.

Detachment instead of attachment ought to be the guiding principle between the teacher and student for the sake of a fair treatment. We may assume that a teacher is a friend with one student and may not be providing special course material to his friend, but still other students may not feel comfortable and raise the issue of favoritism in the class [3]. The issue of favoritism affects teacher's credentials and ability. However, it may be noted that if a teacher is not a friend of any student in the class, then it does not mean that he does not care for students. Rather, he maintains a rationally balanced caring approach towards all his students in the class [7]. He works, moreover, to protect the autonomy of his students in the class.

\section{AN ASSESSMENT OF AUTONOMY OF STUDENTS IN THE ClASSROOM}

Autonomy of a student plays an important role in the overall growth of a student in the classroom. It implies that there should be no advocacy of a teacher in the classroom, which means, as if a teacher presents certain academic views and positions as his own that may elicit students' agreement [6], for example in regard to the topic of abortion or the topic of euthanasia because if he does so, it affects the development of students' autonomy. It may be argued that there can be no single ultimate objective truth of any worldly phenomenon. Discussions and critical reflections on a specific topic are 
possible in the classroom particularly when the issues are socio-political and part and parcel of courses of humanities and social sciences. The student ought to be given autonomy to critically think and analyze on any given particular topic in the classroom. Kupperman contends, "Ideally, higher education will give us graduates who can think for themselves on moral, political and social issues and on issues that arise within academic disciplines, even if this takes time and even if there are no easy answers [6]."

Advocacy in the classroom by the teacher on the issues related to moral, social, economic or political domains is considered to be questionable because such issues are dependent upon real life experiences of individuals and societies and such experiences remain dynamic in nature. Students in the classroom should not be considered as robots who need to be programed for any future course of action. Instead, students are thinking human beings and it is the responsibility of a teacher to help students to think independently in a critical and logical manner.

It is the duty of a teacher to give right answers to the students. Sometimes, it is possible that there is no answer to a specific problem. In such a condition, both the teacher and the student may reflect on the specific problem for discovering an answer. This leads to the encouraging development of the student's critical thinking. This is why; a teacher needs to appreciate the student's own independent reflections on a given specific issue in the classroom. There may be more than two positions, which are supported by valid arguments on a given specific issue, so a reasonable comparison is always possible to make in the classroom. The teacher can try for a desirable balance between personal independent thought and appreciation of the ideas of others [6].

And it goes without saying that autonomy is regarded as an ability of making rational judgements. It comes with the responsibility of being answerable for our own actions. It varies from person to person. It leads to the self-determining factor of an individual. If a student is trained to be autonomous then it will be difficult for the world to manipulate him in future. On the other side, coercion of any sort is regarded as a threat to autonomy of the student in the classroom. Advocacy in the classroom is considered as a form of coercion and it can affect the autonomy of the students, which is why, it is considered to be morally impermissible [6]. We sum up the point in Kupperman's own words, "The skills of autonomy - especially in relation to moral, political and social issues - are part of what should learned in college. To engage in advocacy in the classroom can undermine these skills, and a good general rule is 'Don't' [6]."

\section{CONCLUSION}

We have presented an account of ethics in higher education by way of projecting democratic aspects of education in general and in the assessment of ethical issues of teacherstudent friendship and autonomy of students in the classroom in particular. We have conclusively noted that a teacher plays an important role in maintaining a democratic environment in the field of higher education. And the democratic environment, it is argued, gets promoted if a caring attitude is spread around but still a teacher avoids friendship with students in order to behave in an impartial and fair manner and the teacher works responsibly to protect students' autonomy while discussing contentious socio-political issues in the classroom.

\section{REFERENCES}

[1] Aristotle, Nicomachean Ethics, Translated by J.A.K. Thomson, Penguin Books, 1976.

[2] W. Beckner, Ethics for Educational Leaders. Boston: Pearson, 2004

[3] Margaret Brockett, "Ethics and Student/Educator Relationships," in Ethics for the Professions, John Rowan \& Samuel Zinaich Jr., Eds. USA: Wadsworth Publishing, pp. 423-427, 2003.

[4] P. Gisbert, Fundamentals of Sociology, 3rd Edition, Hyderabad, India: Orient Blackswan Private Limited, 2010.

[5] Amy Gutmann, "Democratic Education, in Ethics for the Professions," in Ethics for the Professions, John Rowan \& Samuel Zinaich Jr., Eds. USA: Wadsworth Publishing, pp. 409-418, 2003.

[6] J. Joel Kupperman, "Autonomy and the Very Limited Role of Advocacy in the Classroom," in Ethics for the Professions, John Rowan \& Samuel Zinaich Jr., Eds. USA: Wadsworth Publishing, pp. 433-439, 2003.

[7] J. Peter Markie, "Professors, Students and Friendship," in Ethics for the Professions, John Rowan \& Samuel Zinaich Jr., Eds. USA: Wadsworth Publishing, pp. 427-432, 2003.

[8] Peter Singer, A Companion to Ethics. Oxford, UK: Blackwell Publishers, 1993.

[9] Noah Webster, "On the Education of Youth in America," in Essays on Education in the Early Republic, Frederick Rudolph, Ed. United Kingdom: Harvard University Press, 1965.

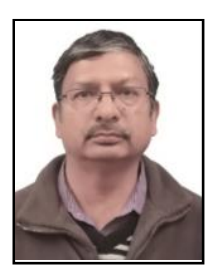

Kumar Neeraj Sachdev was born in Faridkot, Punjab, India on September 4. He was awarded MA in Philosophy from Panjab University, Chandigarh, India in 1987; MPhil in Philosophy from Panjab University, Chandigarh, India in 1990; PhD in Philosophy from IIT, Kanpur, India in 1999.

He is working as an ASSOCIATE PROFESSOR of Philosophy in the Department of Humanities and Social Sciences, BITS, Pilani, Rajasthan, India. He is involved in teaching courses namely Professional Ethics and Applied Philosophy. He has contributed more than seventy-five papers and book reviews on various aspects of philosophical and ethical thought in reputed journals, books, and conferences. He has authored a book entitled "Ethics: A Virtue Theoretic Approach" (2005) and co-edited a volume on "Perspectives on Indian Ethics" (2007). He has to his credit a UGC Minor Research Project on "Relevance of Advaita Ethics Today" (2002-2003); an Indian Council of Philosophical Research (ICPR), New Delhi, India funded research project on "A Normative Analysis of Selflessness as the Inner Perspective of Good Life" (2012-2014); and an Indian Council of Philosophical Research (ICPR), New Delhi, India funded research project on "A Conceptual Study of Human Life: With Special Reference to Patanjali's Yoga-Sutra" (2020-2022). His areas of research interest are Normative Ethics; Ethical Issues in Business and Professions; and Indian Philosophy.

Prof. Sachdev is a Life Member of Indian Philosophical Congress, New Delhi, India; a Life Member of Social Science \& Humanities Research Association (SSHRA) [http://www.eurasiaresearch.org/]; Technical Paper Reviewer, Annals of Bioethics \& Clinical Applications, Medwin Publishers, Troy, Michigan, USA (2019-2020); Technical Paper Reviewer, People: International Journal of Social Sciences (Open access, peer-reviewed and refereed journal published by GRDS Publishing) (2019).

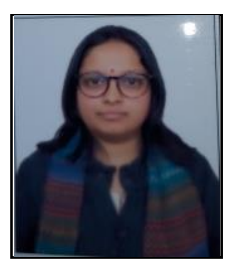

Chetna Gupta was born in Delhi, India in the month of May 1989. She was awarded her B.A. (Hons.) in Philosophy from Daulat Ram College, University of Delhi, India in 2010, M.A. in Philosophy from Ramjas College, University of Delhi, India in 2012 and MPhil in Philosophy in 2018 from Department of Philosophy, University of Delhi, India. Chetna Gupta is currently enrolled as a PhD Research Scholar in the Department of Humanities and Social Sciences, BITS Pilani, Rajasthan India.

She is working in the Department of Philosophy, Shyama Prasad Mukherji College for Women, University of Delhi, India as an 
ASSISTANT PROFESSOR. She has authored three books namely Tagore and Vivekanda's Views on Education: Philosophical and Contemporaray Evaluation (New Delhi, India: Shivalik Prakashan, 2019), Darshanshastra: Shabd Sandarb, Cinema, Kala, Prabodhan Aur Rashtravad (New Delhi, India: Shivalik Prakashan, 2019), UGC Net/Set (JRF \& LS) Philosophy, 4th Edition (New Delhi, India: Arihan Publications, 2018). She has published eleven research papers in various National and International journals. She has presented twenty-six papers in various National and International Seminars/ Conferences. Her research interests are in Philosophy of Education, Ethics, Logic, Social and Political Philosophy, Indian Philosophy and Art and Film Appreciation

Ms. Gupta is a member of National Advisory Board for the Centre for Positive Philosophy and Interdisciplinary Studies and Society for Positive Philosophy and Interdisciplinary Studies, Haryana, India. Ms. Gupta is also a member of Editorial Advisory Board for Lokayata: Journal of Positive Philosophy and Milestone Education Review. 